UDC 1/14:81:94:316

Davit MOSINYAN

\title{
LANGUAGE AND EXPERIENCE IN THE POST-GENOCIDE SOCIETY
}

\begin{abstract}
This paper discusses theoretical and methodological issues concerning the relationship between language-history and experience-memory in post-genocide societies. Here an attempt is made to show how it is possible to remember the past and with the same time to avoid the overwhelming influence of foregoing trauma.
\end{abstract}

Keywords: language, experience, pre-linguistic experience, history, memory, genocide, past, presence, otherness.

Societies differ not only in what they do now, in present, but also what they did in the past. More precisely, some events have taken place in the past of societies which are currently the basis for their differences in the present. Among other differences, there is also one - the presence or absence of genocide in the past. Why the genocide becomes an indicator for differences, or why the post-genocide society becomes an object for a study? For it is extremely important not only to recognize the past of society, but also to understand the present and predict the future. This importance is reflected in the fact that it is merely an illusion that people understand what has happened in the past with them. In response to Winston Churchill's characterization that "we are in the presence of a crime without a name", Raphael Lemkin gave the name 'genocide' (Lemkin, 1946, pp. 227-228), and it seems that the issue was resolved by this. However, that only at first glance it might seem: no matter how Lemkin explained the origin of the name; in fact, the problem start- ed after that name in certain way. "'Genocide' is, in the first place, a word. ... The history of words is not, of course, the same as the history of ideas. It may be that 'genocide' represents different ideas embedded in different theories. ... Words can be powerful, and powerful words can be confusing. ... We have to seek control over our language if we are to grasp the terrible realities to which they somehow refer" (Freeman, 1991, p. 3). The word is the only way to start an analysis, but unfortunately it is a deadlock way. From the moment when we start to believe the language, it imprisons us, and we deprive ourselves of the experience, the reality of which had or could have in the pre-linguistic period. It means that when we verbalize events taking place about us, our impressions and experience undergo the language through which they manifest themselves. When we talk about our tragedy, we feel relieved. In other words, we express the experience which seemed to us incredible great, and it stops being so great because we can now just point to 
it. This means that a linguistic unit reveals relevant experience in the association, and there will no longer need to make the effort to survive for previous experience. One can find an interesting illustration in Leo Tolstoy's "War and Peace"1. Similarly, as soon as the evidence is becoming an archive it stops being an experience. In this sense, famous words from Kafka can be the best epigraph or axis to our topic: "We photograph things in order to drive them out of our minds".

The difficulty of the issue is as follows: the first condition to resolve the problems concerning to the past is memory; but is there any memory or experience beyond the language? This question was originally discussed in epistemology and later was transferred from there to the other fields. Since the XVII century the main epistemological issue was the following: from where does come human knowledge and what is the basic tool to distinguish the truth from a false? In response to this question two epistemological systems

“'That's a fine death!' said Napoleon as he gazed at Bolkonski. Prince Andrew understood that this was said of him and that it was Napoleon who said it. He heard the speaker addressed as Sire. But he heard the words as he might have heard the buzzing of a fly. Not only did they not interest him, but he took no notice of them and at once forgot them. His head was burning, he felt himself bleeding to death, and he saw above him the remote, lofty, and everlasting sky. He knew it was Napoleon his hero but at that moment Napoleon seemed to him such a small, insignificant creature compared with what was passing now between himself and that lofty infinite sky with the clouds flying over it." (Leo Tolstoy, War and Peace. Translated by Louise and Aylmer Maude. 2009, p. 532). were developed - rationalism and empiricism. Rationalists claim that all we know by reason is superior in a philosophical way. And empiricists state that knowledge comes primarily from experience. However, after Kant and Hegel who combined those two systems, the question changed a little bit. There were authors among both analytic and continental philosophers who asserted that the only possible object of philosophy is language. And after that the question was in epistemology raised in the following way: is there any experience beyond the language, or language goes all the way down? Rorty, for instance, from the point of linguistic transcendentalism categorically rejects the possibility of pre-linguistic experience, stating that every experience is given in the language, including the experience of the self. He nevertheless underlines the exception of pain as being pre-linguistic (see Rorty, 1989, p. 94). Because pain is a total phenomenon, it at once subdues the whole system, organism; total pain can even stop the process of thinking and to represent itself as the primary substance. If there is pain, you belong to him, not vice versa. A similar question has also raised Georges $\mathrm{Ba}$ taille in his famous Inner Experience. He argues that it is impossible to define the experience. He rather means the experience in the broadest sense - the experience of the death. And it is connected with our topic. From the viewpoint of our issue, the question is more complicated: is it possible to feel someone else's pain or to have the same consciousness as people who lived in the past? By the way, it is a cornerstone of historicism. This is an issue which originally was discussed in Thomas Nagel's essay with interesting title 'What is it like to be a bat?' The main idea of 
this essay is that even if we succeed in this matter we can answer the question 'what a bat is for us', but we cannot grasp the inner life of a bat. "If anyone is inclined to deny that we can believe in the existence of facts like this whose exact nature we cannot possibly conceive, he should reflect thatin contemplating the bats we are in much the same position that intelligent bats or Martians would occupy if they tried to form a conception of what it was like to be us. The structure of their own minds might make it impossible for them to succeed, but we know they would be wrong to conclude that there is not anything precise that it is like to be us: that only certain general types of mental state could be ascribed to us" (Nagel, 1974, p. 440). The problem would be solved if there is a psychophysical neutral language, into which the languages of man and bat would be translated. Nevertheless, there is no such language. We cannot get rid of our language. From there, an interesting and obligatory thesis: "Subjectivity is the only way to objectivity, to the world of objects" (Ankersmit, 2005, p. 102).

Now, if we move our reflections on our mail topic, i.e. to compare bat with the past, we have to accept that "we can no longer separate the experience from what it is an experience $o f$ : The past then comes into being only because a certain social and mental world is experienced as past. That is to say, there is not, first, a past, and next, an experience of this past (in the way that there is, first, this chair and, next, my experience of it). The experience of the past and the past itself (as a potential object of historical research) are born at one and the same moment, and in this way experience can be said to be constitutive of the past" (Ankersmit, 2005, p. 102). In this sense, the problems of the past are always present problems, as they manifest themselves in the present. On the other hand, certain episodes of the past are frequently manifest themselves because they are not a part of us. It is not ours but is very important for us, as it constantly reminds about him. So, to speak of the post-genocide society means to pay attention to the genocide which constantly reminds about itself. And once again formulating our main problem, it would be as follows: how to deal with this terrible episode of the past? Past, especially if it is traumatic, is a barrier that does not allow moving forward, does not allow our knowledge to become a life. How is it possible to get rid of the trauma of the past? You cannot alienate, deny it, because it is yours! On the other hand, forgetting is not the best way to resolve the problem, because "forgetting extermination is part of extermination, because it is also the extermination of memory, of history, of the social, etc." (Baudrillard, 1981, p. 77). If you didn't suppress it before, in the past, then now you should recognize it face to face, in other words, narrate it. Only if a trauma becomes a narrative, then it will lose its terrible power. By the way, in this regard, an analogy can be drawn between experience and memory, on the one hand, and language and history, on the other hand. First, perhaps, Maurice Halbwachs has talked about the contradiction of history and memory, stating that the history begins where the memory ends. Not only Halbwachs, but other thinkers like him, began to speak on this topic. For instance, Pierre Nora: "Memory and history, far from being synonymous, appear now to be in fundamental opposition. Memory is life, borne by living societies founded in its name. ... History, on the other hand, is the reconstruction, always problematic and incomplete, 
of what is no longer. Memory is a perpetually actual phenomenon, a bod tying us to the eternal present; history is a representation of the past" (Nora, 1989, p. 8). Aleida Assmann continues the theme and notices that the relation between history and memory has itself a history that has evolved over time, passing through three stages: the identity between history and memory, the polarization between history and memory, and the interaction between history and memory (see Assmann, 2008, p. 57). So, in other words, if we say the same by new terminology, we would mention that post-genocide society demands to transform memory into history or to make memory audible, because "the memory evicted from the history is a psychological, individual, museum exponent that is not able to create new communication-information streams" (Hovhannisyan, 2014, p. 89).

However, there is a danger here: the danger is not only in respect with the loss of former identity (i.e. not only is social-psychological), but also is pure cognitive. When you appear in the linguistic field or deal with narratives, you lose the chance of experience. The point is that ''genocide' can never be identified purely by 'value-free', empirical observation but always requires a normative judgment" (Freeman, 1991, p. 6). Language is a prison that deprives us of the opportunity to see things in a pure manner. Although the language reveals the linguistic dimension of the world, where things are not represented in one aspect only, but as a whole essence, it is more than personal experience, in the sense that no one can see what denote the word 'genocide'. Moreover, as the Word of God created the world, one may agree that "language is not metaphorical but the world as we know it is an imperfect metaphor of the real world of the Word" (Vanderjagt, 1996, p. 342).

Thus, there is a possibility of choice which depends on the dreams of post-genocide society.

\section{REFERENCES}

Ankersmit, F. (2005). Sublime Historical Experience. Stanford University Press.

Assmann, A. (2008, Spring). Transformations between History and Memory. Social Research, 75(1), 49-71.

Baudrillard, J. (1981). Simulacra et simulation. Galilée.

Freeman, M. (1991). Speaking about the Unspeakable: Genocide and Philosophy. Journal of Applied Philosophy, 8(1), 3-17.

Hovhannisyan, S. (2014). Memory and History. The Problem of Hierarchy of Genocides in Pierre Nora's Theory. Yerevan: Antares.

Lemkin, R. (1946, Spring). Genocide. The American Scholar, 15(2), 227-230.

Nagel, Th. (1974, October). What is it like to be a Bat? The Philosophical Review, 83(4), 435-450.

Nora, P. (1989, Spring). Between Memory and History: Les Lieux de Mémoire. Representations, 26(Special Issue: Memory and Counter Memory), 7-24.

Rorty, R. (1989). Contingency, Irony, and Solidarity. Cambridge University Press.

Vanderjagt, A. (1996). Bernard of Clairvaux and Aelred of Rievaulx. Instrumenta Patristica XXVII: Media latinitas, 339-343. doi: 10.1484/M.IPMEB.4.001114 